Joanna Gul

ORCID: 0000-0001-5045-8640

Uniwersytet Wrocławski

\title{
Lira na okładkach nut
}

Abstrakt: Tekst dotyczy grafiki na okładkach nut w XIX i pierwszej połowie XX wieku związanej z instrumentami muzycznymi. Jednym z najczęściej pojawiających się instrumentów na okładkach nut jest antyczna lira, najważniejszy instrument starożytnej Grecji. Mimo że nie jest używana w praktyce muzycznej Zachodu od setek lat, wciąż utrzymuje się jej znaczenie jako symbolu muzyki, zwłaszcza wokalno-instrumentalnej. Na okładkach nut występuje w różnych funkcjach, od (często mało zauważalnych) znaków graficznych (sygnetów) wydawnictw muzycznych, przez małe elementy zdobnicze po ilustracje całej okładki. Zgodnie z konwencją lira jest przedstawiana samodzielnie lub w rękach muz, niekiedy wizualnie uwspółcześnionych, a nawet symbolizujących sztukę ludową. Choć najbardziej popularnym instrumentem w praktyce muzycznej XIX i XX wieku był fortepian, nierzadko obecny w ilustracjach nut, w plastyce nie osiągnął znaczenia podobnego do liry. Tymczasem antyczna lira wciąż jest uniwersalnym symbolem sztuk muzycznych. Wydaje się, że współcześnie zanika rozpoznawalność zarówno instrumentu, jak i treści symbolicznych oraz odniesień mitologicznych i religijnych, które niesie.

Słowa-klucze: instrumenty muzyczne, nuty, okładki nut, ilustracje okładek, lira, antyczna lira, symbolika liry, Apollo, muzy, fortepian, znak graficzny wydawnictwa (sygnet), ikonografia muzyczna

Niniejszy tekst jest próbą nakreślenia zagadnień związanych z wizerunkami instrumentów muzycznych umieszczanych na ilustrowanych okładkach nut, publikowanych w XIX i XX wieku, ze szczególnym uwzględnieniem liry. Termin „okładka” jest tu traktowany umownie, z powodu przeróżnej konstrukcji druków muzycznych, często odmiennej od książek. Niekiedy bogato ilustrowana jest strona tytułowa zamiast okładki (zdarza się to także w tak zwanych klockach, czyli zbiorach kilku lub więcej pojedynczych nut, składanych w jeden wolumin przez introligatora), ponadto konstrukcja nut bywa tak nieskomplikowana jak arkusz złożony na pół, na którego zewnętrznych stronach nadrukowana jest treść okładki, a zapis muzyczny znajduje się na wewnętrznych stronach tego samego arkusza (w takich przypadkach brakuje funkcji ochronnej, którą okładka powinna pełnić względem wnętrza druku).

Współczesna tendencja do digitalizacji zbiorów bibliotecznych sprawia, że materiały do analizy druków muzycznych są właściwie nieprzebrane i mogą być punktem wyjścia do badań o bogatej tematyce. Materiał, który mnie zainspirował 
i do którego odnoszę się w artykule, pochodzi z Biblioteki Kulturoznawstwa i Muzykologii Uniwersytetu Wrocławskiego, kolekcji prywatnych prof. Pawła Banasia oraz śp. Andrzeja Dorędy, a także zdigitalizowanych zbiorów nut z bibliotek na całym świecie, jak polskie biblioteki cyfrowe, zwłaszcza Polona, oraz zagraniczne, jak Biblioteka Kongresu ${ }^{1}$, Biblioteka Uniwersytetu Duke ${ }^{2}$ itp. Niektóre kolekcje prywatne są opracowane i udostępnione przez właścicieli — przydatne były zwłaszcza polska witryna Stare Melodie $^{3}$ oraz belgijska Images Musicales, szczegółowo posegregowana pod względem tematyki okładek, ilustratorów itp. ${ }^{4}$

Polska literatura dotycząca ikonografii i ikonologii muzycznej ${ }^{5}$ jest dość obszerna, jednak w jej ramach ilustrowane okładki nut z XIX i XX wieku jako obiekt analizy występowały rzadko. Lekcja $z$ nut Andrzeja Banacha ${ }^{6}$ jest bodaj pierwszym w języku polskim, rozległym i erudycyjnym ujęciem zagadnienia ilustrowanych nut. Po przekrojowej, ale wydanej już pięćdziesiąt lat temu publikacji Banacha temat ten jest rzadko podejmowany, być może z powodu jego kłopotliwej interdyscyplinarności. Autorzy poruszający się w sferze grafiki użytkowej na ogół nie traktują ikonografii muzycznej lub ilustracji druków muzycznych jako odrębnych pól badawczych. Graficy ilustrujący nuty byli też zwykle autorami plastycznych kompozycji książek, plakatów, druków użytkowych, stąd tematyka muzyczna $\mathrm{w}$ ich działalności jest traktowana jak jeden $\mathrm{z}$ wielu elementów, nie najważniejszy, i z tego powodu często pomijana. Ilustracje z okładek nut w sposób naturalny ujmowane są w publikacjach dotyczących ilustracji książkowej. W Dostownie. Liternicze i typograficzne okladki polskich książek 1944-2019 autor Janusz Górski ${ }^{7}$ podał jako przykłady między innymi kilka nut oraz książek o tematyce muzycznej. Głównym tematem monografii autorstwa Justyny Nowickiej 70 na 70. Projektowanie graficzne w PWM w latach $1945-2015^{8}$, wydanej na siedemdziesięciolecie Polskiego Wydawnictwa Muzycznego, jest oprawa plastyczna publikacji o treści muzycznej (książek i nut) oraz sylwetki grafików związanych z PWM, wśród których byli najwybitniejsi ilustratorzy w Polsce. Okładki nut nie są tu jednak przedmiotem głębszej analizy. Ciekawym przykładem przekrojowego albumu z okładkami jest Tysiac polskich okładek Aleksandry i Daniela Mizielińskich",

${ }^{1}$ Library of Congress, Music for the Nation: American Sheet Music, ca. 1870 to 1885, https:// www.loc.gov/collections/american-sheet-music-1870-to-1885/ (dostęp: 1.04.2021).

${ }^{2}$ Historic American Sheet Music, https://repository.duke.edu/dc/hasm (dostęp: 1.04.2021).

3 https://staremelodie.pl (dostęp: 25.05.2021).

${ }^{4} \mathrm{Na}$ temat kolekcji zob. https://imagesmusicales.be/about/8/ (dostęp: 1.04.2021).

5 Por. Muzyka w sztukach wizualnych XIX-XXI wieku, red. J. Guzy-Pasiak, Warszawa 2013 (Ikonografia muzyczna. Studia i materiaty, t. 2), wstęp, s. 7-8.

6 A. Banach, Lekcja z nut, Kraków 1971.

7 J. Górski, Dostownie. Liternicze i typograficzne okładki polskich ksiązek 1944-2019, Kraków 2019.

8 J. Nowicka, 70 na 70. Projektowanie graficzne w PWM w latach 1945-2015, Kraków 2015.

9 Tysiąc polskich okładek, wybór A. i D. Mizielińscy, Warszawa 2010. Liczbowanie stron w tej publikacji odpowiada numerom kolejnych ilustracji. 
który, poza krótkim wstępem, składa się wyłącznie z ilustracji. Autorzy dokonali wyboru tysiąca kolorowych okładek polskich książek, w tym także nielicznych o tematyce muzycznej oraz nut. Uwzględnienie ich w Tysiacu polskich okładek wskazuje na wartość oprawy druków muzycznych na gruncie polskiej grafiki użytkowej. Marcin Zgliński jest prawdopodobnie pierwszym polskim autorem, po Andrzeju Banachu, traktującym ilustrowane okładki polskich nut jako autonomiczny przedmiot będący nośnikiem istotnych znaczeń. W artykule Cover design in editions of Polish propaganda songs, $1945-1955^{10}$ analizuje on okładki pieśni, spoglądając przez ich pryzmat na przemiany społeczno-polityczno-artystyczne okresu wczesnej PRL. W literaturze zagranicznej tradycja badania okładek nut odrębnie od książek jest bogatsza, a ilustracje druków muzycznych są materiałem do badania wybranych zjawisk w kulturze, jak postrzeganie starości ${ }^{11}$ czy stereotypowe wizerunki kobiet Orientu ${ }^{12}$.

Warto wspomnieć, że do traktowania ilustrowanych okładek nut jako wartościowych, ciekawych i autonomicznych obiektów przyczyniły się wystawy kolekcji nut, z których prawdopodobnie pierwsza, prezentująca zbiory prof. Pawła Banasia stała się punktem wyjścia do opracowania tego tekstu ${ }^{13}$.

\section{Okładki liternicze i ilustrowane}

Okładki nut zasługują na odrębne potraktowanie, ponieważ często są wyposażone w cechy wyraźnie odróżniające je od okładek książek. Ilustrator zwykle nawiązuje do tekstu utworów wokalnych czy programu literackiego w utworze muzycznym, a także użytego instrumentarium. Wśród wielu innych różnic są

${ }^{10}$ M. Zgliński, Cover design in editions of Polish propaganda songs, 1945-1955, [w:] Music, Politics and Ideology in the Visual Arts, red. P. Gancarczyk, D. Grabiec, Warszawa 2015 (Ikonografia muzyczna. Studia i materiaty, t. 3).

11 E.S. Cohen, A.L. Kruschwitz, Old age in America represented in nineteenth and twentieth century popular sheet music, „The Gerontologist” 30, 1990, nr 3, s. 345-354, cyt. za: J.M. Łubocki, Okładki druków muzycznych jako ważne zagadnienie badawcze: na marginesie wystawy Obrazki z nut (Wroctaw, 19 stycznia-28 lutego 2018), „Studia o Książce i Informacji” 37, 2018, s. 218; zob. też idem, Funkcje okładek dokumentów muzycznych w perspektywie okładkoznawstwa, w niniejszym tomie.

12 Ch.A. Kennedy, "Becky from Babylon" and Other Oriental Beauties: Images of Middle Eastern Women in Twentieth-Century Sheet Music, „Music in Art” 42, 2017, nr 1-2, s. 353-365.

13 Obrazki z nut. Druki muzyczne od końca XIX do połowy XX wieku z kolekcji Pawła Banasia. Wystawa w Dolnoślaskiej Bibliotece Publicznej im. Tadeusza Mikulskiego we Wrocławiu. Styczeń/ luty 2018, red. J. Czarnik, A. Ćwik, Wrocław 2018. Zainspirowała ona kolejną wystawę okładek nut z XIX i XX wieku z kolekcji wspomnianego już Andrzeja Dorędy, bydgoskiego stroiciela fortepianów. Ekspozycja, którą współtworzyłam, została zaprezentowana podczas III Ogólnopolskiej Konferencji Instrumentologicznej w Ostromecku koło Bydgoszczy w 2019 roku, zob. http://konfe rencjainstrumentologiczna.pl/1320 (dostęp: 25.05.2021). 
uwarunkowania wydawnicze, takie jak popularność nut, szybkość publikowania, duże nakłady, szczególny profil odbiorców itp. Ilustrowane nuty z przełomu XIX i XX wieku są mocno związane z kulturą popularną, przemianami obyczajów, intensywnym rozwojem nowych gatunków muzyki i tańca, a także fonografii, która współdziałała z rynkiem wydawniczym nut między innymi przez zamieszczanie reklam nagrań utworów.

Przytaczając argumenty na rzecz odrębności okładek nut od książkowych, trzeba też przyznać, że w dużej części egzemplarzy nie różnią się one od siebie. Znaczna część okładek nut jest po prostu liternicza (typograficzna) — zawiera jedynie zakomponowany graficznie tekst, $\mathrm{w}$ tym tak zwane tytularia ${ }^{14}$ - nazwisko kompozytora, tytuł utworu z obsadą instrumentalną, niekiedy inne treści. Pozbawione ilustracji okładki liternicze (ewentualnie ozdobione delikatnymi bordiurami) towarzyszą zwykle - podobnie jak w wypadku książek — publikacjom dla profesjonalistów, takim jak partytury dla dyrygentów i zaawansowanych instrumentalistów, formaty „kieszonkowe" nut, przydatne w analizie utworu studentom czy melomanom, czy ,pomnikowe” serie poświęcone wybranemu kompozytorowi, bez względu na stopień trudności utworów, jak na przykład Wydanie Narodowe Dzieł Fryderyka Chopina pod redakcją Jana Ekiera i Pawła Kamińskiego, ozdobione jedynie skrótowym podpisem kompozytora (który został użyty w funkcji znaku graficznego serii) ${ }^{15}$. Granica nie jest tu ostra, ale najczęściej po stronie muzycznych druków ilustrowanych znajdziemy repertuar salonowy i rozrywkowy z XIX i XX wieku, często partytury oper, zapewne ze względu na wizualność wpisaną w ten gatunek, oraz nuty dla dzieci i młodzieży. Wśród tych ostatnich nie wszystkie okładki są ilustrowane, przykładowo znane każdemu młodemu muzykowi kilkadziesiąt lat temu serie dydaktyczne, publikowane przez PWM (w ramach których wydano na przykład Inwencje Bacha czy Etiudy Czernego) były opatrzone okładkami literniczymi, ożywionymi jedynie kolorystyką, odrębną dla różnych instrumentów (fortepianowi przypadł dość posępny fiolet ${ }^{16}$ ). Pod tym względem w ostatnich latach zaszły daleko idące zmiany - wiele publikacji zawierających podstawowe dla młodego muzyka utwory otrzymało kolorowe, ilustrowane okładki, co jednak nie zawsze idzie w parze $\mathrm{z}$ dobrym poziomem graficznym. Jednak nawet okładki nut pozbawione ilustracji często noszą symbol stricte muzyczny, ujęty w znaku graficznym wydawnictwa.

14 Określenia dotyczące składników grafiki książkowej (tytularia, sygnet, ozdobnik itp.) za: J. Górski, op. cit.

15 Zob. https://www.chopin-nationaledition.com/sklep/?lang=pl (dostęp: 25.05.2021).

16 Na przykład wydane w kontynuowanej od lat kolorystyce: J.S. Bach, Inwencje dwugłosowe na fortepian, Kraków 2020, https://pwm.com.pl/pl/sklep/publikacja/inwencje-dwuglosowe,johann -sebastian-bach,536,ksiegarnia.htm (dostęp: 24.05.2021). 


\section{Lira - charakterystyka instrumentu}

Prawdopodobnie najczęściej występującym na okładkach nut w XIX i XX wieku instrumentem muzycznym jest lira - znana w Azji i Afryce w czasach starożytnych, stała się najważniejszym instrumentem antycznej Grecji. Pod tą nazwą kryje się kilka form instrumentu, od prostej konstrukcji z korpusem rezonansowym wykonanym ze skorupy żółwia, owocu bądź drewnianej niecki pokrytej skórą, do której przymocowane są dwa ramiona (z rogów zwierzęcych lub drewniane), po najbardziej zaawansowaną, ozdobną formę - kitarę (kitharę), często bogato dekorowaną, o korpusie w formie płaskiej, drewnianej skrzynki zakończonej szerokimi, pustymi wewnątrz ramionami ${ }^{17}$. Charakterystyczne dla wszystkich odmian lir są rozmieszczone po obu stronach instrumentu dwa ramiona, na ogół tej samej długości, złączone poprzeczką zwaną jarzmem, do której przymocowanych jest od trzech do dwunastu strun, biegnących pionowo do korpusu rezonansowego instrumentu, szarpanych palcami lub plektronem. W ikonografii nowożytnej zwykle spotykamy liry trzy- lub siedmiostrunowe (środkowa struna tworzy oś symetrii), ponadto lira nosi już zwykle cechy stylizacji ${ }^{18}$. Powodem, dla którego często sięgano po graficzny znak liry, jest prawdopodobnie jej harmonijna symetryczna forma, możliwa do naszkicowania kilkoma kreskami. Jednak ważniejszym powodem jest symboliczne znaczenie liry, sięgające głębokich warstw kultury europejskiej, starożytnych mitów i tekstów. Antyczna lira jest instrumentem boskim - według mitów została zbudowana przez Hermesa i podarowana Apollinowi, bogu muzyki i tańca oraz wszystkich sztuk. Jest też atrybutem muz — Erato, opiekunki poezji miłosnej, oraz Terpsychory, opiekunki tańca i pieśni. Jako instrument strunowy związany z duchowością apollińską lira jest stawiana w opozycji do instrumentów dętych, związanych z dionizyjską zmysłowością. $\mathrm{Na}$ niej akompaniowali sobie do śpiewu Orfeusz, a także śmiertelnicy-poeci, jak Homer (nazywający kitarę formingą) czy Horacy ${ }^{19}$. Wizerunek liry jest też związany ze starotestamentowym królem Dawidem i w konsekwencji z chrześcijaństwem. Choć rozstrzygnięcie, na jakim instrumencie mógł grać król Dawid, dzisiaj jest

17 C. Sachs, Historia instrumentów muzycznych, przeł. S. Olędzki, Warszawa 2005, s. 116-125; K. Wachsmann et al., Lyre, [w:] The Grove Dictionary of Musical Instruments, red. L. Libin, t. 3, New York 2014, s. 344-347.

18 Opisując liry umieszczone na ilustracjach, używam określeń „lira” (jako nazwy ogólnej, ujmującej różne odmiany lir) oraz „kitara” (gdy wygląd instrumentu wyraźnie na nią wskazuje), ponieważ w ikonografii XIX i XX wieku liry często noszą cechy stylizacji, co sprawia, że przyporządkowanie ich do szczegółowych grup lir starożytnych, rozróżnianych w instrumentologii, nie ma uzasadnienia.

19 Mata encyklopedia kultury antycznej, red. Z. Piszczek, Warszawa 1983, passim; Encyklopedia muzyki, red. A. Chodkowski, Warszawa 2001, passim; C. Sachs, op. cit. 
już niemożliwe ${ }^{20}$, zwyczajowo przedstawia się go z harfą lub lirą (kitarą), znacznie rzadziej z innymi instrumentami strunowymi ${ }^{21}$. W chrześcijaństwie lirę, a także inne instrumenty strunowe, łączono z postacią Chrystusa, między innymi przez nawiązanie do jego przodka Dawida, postaci Apolla-zbawiciela (o symbolu słońca) i porównanie do mitycznego Orfeusza, posiadającego nadzwyczajną władzę nad naturą. Siedem strun liry interpretowano między innymi jako symbol harmonii świata czy siedmiu planet ${ }^{22}$. Lira jest też instrumentem muzycznym (jednym z wielu) św. Cecylii, patronki muzyki.

Ciekawe jest przy tym, że starożytna lira, najważniejszy instrument Grecji okresu klasycznego, znacząca także w Rzymie, od wieków nie istnieje już w praktyce muzycznej Zachodu. Instrumenty zbliżone do prostej liry greckiej (z korpusem rezonansowym ze skorupy zwierzęcia czy owocu) spotyka się współcześnie jedynie w Afryce ${ }^{23}$. Starożytna lira w kulturze Zachodu funkcjonuje już tylko jako rekwizyt teatralny oraz ważny element ikonografii muzycznej. Była niezwykle popularnym symbolem muzyki, szczególnie wokalnej i wokalno-instrumentalnej (zgodnie z antyczną zasadą akompaniowania na lirze do śpiewu lub deklamacji). Zwłaszcza w XIX wieku jej wizerunek umieszczano jako dekorację na różnorodnych drukach i przedmiotach związanych z muzyką, na przykład śpiewnikach, meblach, batutach dyrygenckich ${ }^{24}$, elementach instrumentów muzycznych czy pomnikach muzyków - przykładowo na epitafium Fryderyka Chopina w bazylice św. Krzyża w Warszawie umieszczono symboliczny znak liry z wawrzynem, a nie najbardziej znaczący dla jego twórczości fortepian. Nazwa „lira” pojawiała się w tytułach śpiewników, serii nut czy jako nazwa zespołów wokalnych i stowarzyszeń muzycznych (w nazewnictwie bardzo popularna była także „lutnia”). W malarstwie muza z lirą pojawia się jako postać w scenach antycznych lub symbol natchnienia artysty - kompozytora czy poety ${ }^{25}$. Warto zauważyć, że najważniejszym instrumentem muzycznym XIX wieku w sferze materialnej był fortepian, lecz to właśnie lira funkcjonowała jako uniwersalny symbol

20 Badacze wskazują jednak na największe prawdopodobieństwo liry, zob. J. Montagu, Instrumenty muzyczne Biblii, przeł. G. Kubies, Kraków 2006, s. 28-29.

21 Na przykład The Beauties of Psalmody: A collection of sacred music..., arr. D. Robertson, Edinburgh, ok. 1800, https://polona.pl/item/the-beauties-of-psalmody-a-collection-of-sacred-musicsuitable-to-public-or-private,MTAxMDA3MzQ1/4/\#info:metadata (dostęp: 1.06.2021).

22 P. Towarek, Chrześcijańska symbolika instrumentów muzycznych, „Studia Elbląskie” 15, 2014, s. 221-232; M. Feuillet, Leksykon symboli chrześcijańskich, przeł. M. Paleń, Poznań 2006; J.E. Cirlot, Stownik symboli, przeł. I. Kania, Kraków 2000.

23 Na przykład etiopska lira beganna. Zob. C. Sachs, op. cit., s. 117-124.

24 Zob. „Batuty w zbiorach polskich”, spośród których bardzo wiele ma dekorację w kształcie liry, www.batuty.instrumenty.edu.pl (dostęp: 1.04.2021).

${ }^{25}$ W tym kręgu tematów wyróżnia się dość wyjątkowe przedstawienie postaci Chopina na rysunku Eli Nadelmana z 1904 roku pt. Chopin — nagi mężczyzna dotyka włosów kochanki-muzy niczym strun liry; A. Melbechowska-Luty, Chopin w malarstwie polskim od romantyzmu do modernizmu, [w:] Chopin w kulturze polskiej, red. M. Gołąb, Wrocław 2009, s. 257. 
muzyki w sferze duchowej. Kształt i nazwa liry są obecne nawet w obudowie fortepianu - część ujmująca dźwignie nożne (pedały) ma kształt i nazwę liry (pedałowej), a w ażurowych pulpitach fortepianów nierzadko wycinano jej ozdobny kontur. Podobnie spotyka się części niektórych instrumentów muzycznych, jak strunociągi, utworzone w dekoracyjnym kształcie liry.

\section{Lira jako sygnet}

Jak już wspomniano, nawet okładki nut pozbawione ilustracji mogą nosić znaki stricte muzyczne, takie jak instrumenty muzyczne, odwzorowane w znaku graficznym wydawnictwa - sygnecie (logo). Przykładowo w znaku graficznym oficyny Glocken-Verlag z Wiednia widnieje klucz wiolinowy na pięciolinii, za nim dzwon $z$ nutą w miejscu serca dzwonu ${ }^{26}$. Wydawnictwo Muzyczne M.I. Weigt z Poznania stosowało wizerunek kamertonu połączonego $\mathrm{z}$ nutami ${ }^{27}$, a bardzo znane Wiener Philharmonischer Verlag firmowało się dość niezwykłym znakiem głowy, otoczonej „kryzą” z instrumentów, podobnych do cytar lub mandolin ${ }^{28}$.

Bardzo często w roli sygnetu wydawnictw muzycznych lub sygnetu serii jest przedstawiona antyczna lira ${ }^{29}$. Znak graficzny wydawnictwa występuje niezależnie od tego, czy okładka jest bujnie ilustrowana, czy też liternicza. Choć wiele wydawnictw stricte muzycznych nie ma żadnych graficznych odniesień do muzyki w swoich znakach firmowych (choćby słynne Bärenreiter czy Breitkopf \& Härtel, sygnujące się sylwetką niedźwiedzia), przykłady zastosowania instrumentów lub symboli muzycznych w sygnetach oficyn publikujących nuty są często spotykane, a wśród nich lira odgrywa główną rolę.

Wymieniając oficyny zagraniczne, można zacząć od Artarii, założonej w Wiedniu w XVIII wieku, współczesnej klasykom wiedeńskim i publikującej ich dzieła, która istnieje do dziś i nadal firmuje się znakiem liry ${ }^{30}$. Wydawnictwo Ernst Eulenburg (założone w 1874 roku w Lipsku), znane zwłaszcza z serii małych, „,kieszonkowych", partytur, których okładki były zdobione tylko winietą ramkową i ozdobnym sygnetem firmy — posługiwało się znakiem liry na czarnym owal-

26 Zob. Der letzte Operettenkönig, https://www.musikundbuehne.de/specials/franz-lehar.html (dostęp: 24.05.2021).

27 Na przykład E. Grieg, Walc op. 12, Poznań 1950, https://polona.pl/item/walc-op-12-na-forte pian,Njg5MDc0NTM/0/\#info:metadata (dostęp: 28.04.2021).

28 Na przykład L. van Beethoven, Symphonie V C-moll, Wien [1923], (Philharmonia Partituren), https://polona.pl/item/symphonie-v-c-moll-c-minor-do-mineur-op-67,ODY3NTMwOTY/0/\#info: metadata (dostęp: 28.04.2021).

29 Nie znając dobrze historii wydawnictwa, trudno niekiedy stwierdzić, czy dany znak był sygnetem, czy też był incydentalnie zastosowany jako ozdobnik.

30 Strona oficyny z sygnetem https://www.artaria.com (dostęp: 1.05.2021). 
nym tle z wplecionym monogramem $\mathrm{EE}^{31}$. Dziś nuty w serii „Eulenburg” (w ramach oficyny Schott ${ }^{32}$ ) są opatrzone unowocześnionym sygnetem w kształcie liry, bez monogramu. Łotewska oficyna Edition Lettonie z Rygi (pierwsza połowa $\mathrm{XX}$ wieku $)^{33}$ umieściła w swoim znaku graficznym pięciolinię, klucz wiolinowy i dwie nuty ujęte między ramionami kitary ${ }^{34}$. Szczególnie ciekawie do poezji antycznej nawiązało nowojorskie wydawnictwo G. Schirmer ${ }^{35}$, które około lat trzydziestych XX wieku stosowało sygnet $\mathrm{z}$ rysunkiem kitary na tle bujnego krzewu, opatrzonej wstęgą ze słowami Laborum dulce lenimen, którymi Horacy w jednej ze swych pieśni sławił własną lirę ${ }^{36}$.

Spośród wydawnictw zagranicznych w bodaj najbardziej oryginalny sposób nawiązała do liry francuska Éditions de l'Oiseau-Lyre (współcześnie część firmy Decca), firmująca płyty z nagraniami, dawniej publikująca także nuty. Obrała sobie za sygnet lirogona - australijskiego ptaka, którego samiec ma pokaźny ogon o niespotykanym kształcie, zdumiewająco przypominającym lirę (po obu stronach ogona znajdują się grubsze pióra, wywinięte na zewnątrz, które obejmują jak struny pióra znacznie cieńsze). Lirogon cechuje się także nadzwyczajnymi umiejętnościami dźwiękonaśladowczymi - potrafi odwzorować zarówno naturalne dźwięki, jak śpiewy innych gatunków ptaków, jak i najbardziej wymyślne, z którymi może się zetknąć: dźwięk migawki aparatu, piły lub strzałów w grze komputerowej itp. ${ }^{37}$ Nuty publikowane w Éditions de l'Oiseau-Lyre na przykład w latach osiemdziesiątych XX wieku mają w znaku wydawnictwa lirogona pre-

31 Na przykład R. Wagner, Tristan und Isolde: Vorspiel und Isoldes Liebestod, Leipzig [ok. 1920], https://polona.pl/item/vorspiel-und-isoldens-liebestod-aus-tristan-und-isolde,MTExMjIyMjc0/0/\#i nfo:metadata (dostęp: 28.04.2021).

${ }^{32}$ Historia firmy zob. https://de.schott-music.com/eulenburg/ueber-eulenburg (dostęp: 1.04.2021).

33 Nie udało się określić lat działalności wydawnictwa, znane nuty Edition Lettonie ze zbiorów prywatnych i publicznych mają okładki o cechach plastycznych stylu secesyjnego.

34 Na przykład H. Wieniawski, Kujawiak, Riga [ok. 1930], https://polona.pl/item/kujawiak-pia no,NzE3MTYxNzY/0/\#info:metadata (dostęp: 28.04.2021).

35 Na przykład H. Panofka, The Art of Singing: Twenty-four vocalizes for Alto, New York [ok. 1930], https://polona.pl/item/the-art-of-singing-twenty-four-vocalises-for-alto-baritone-orbass-op-81,OTQzMTc1ODA/4/\#info:metadata (dostęp: 1.05.2021).

36 Dosłownie „słodka ulgo od trudów” - przeł. Alina Komsta, której bardzo dziękuję. W wielu polskich tłumaczeniach tej pieśni opiewającej lirę (księga I, pieśń 32) użyte jest słowo „lutnia”, jak w przekładzie Jana Sękowskiego: „Jowisz przy ucztach radował się tobą / Ty płoszysz troski, o Feba ozdobo! / Przybądź gdy znajdę cię, lutnio, w potrzebie / I wezwę Ciebie”. Kwintus Horacjusz Flakkus, Dzieła wszystkie, t. 1, oprac. O. Jurewicz, przeł. J. Sękowski, Wrocław 1986, s. 138. Oddanie w języku polskim liry jako lutni ma tradycję co najmniej od tłumaczeń Jana Kochanowskiego, być może powodem była wysoka pozycja lutni w czasach Jana z Czarnolasu, a nieobecność w praktyce muzycznej takiego instrumentu jak lira.

37 Zob. na przykład film w serii „BBC Earth”: Attenborough: the amazing Lyre Bird sings like a chainsaw! Now in high quality, https://www.youtube.com/watch? $=\mathrm{v}=\mathrm{mB} 71 \mathrm{jNq}-\mathrm{yQ}$ (dostęp: 1.04.2021). 
zentującego ogon w pozycji bez wątpliwości podobnej do liry ${ }^{38}$. Dziś znak serii „l'Oiseau-Lyre” jest bardziej subtelny, obejmuje całą ptasią sylwetkę lirogona $\mathrm{z}$ pokaźnym ogonem ujętą $\mathrm{z}$ boku - $\mathrm{w}$ ten sposób już nie bezpośrednio wizerunek, ale nazwa wskazuje na konotacje $\mathrm{z}$ instrumentem muzycznym.

W sygnetach polskich oficyn muzycznych lub wydawanych przez nie serii lira także jest często spotykana. Zaczynając od przedwojennych, Wydawnictwo Muzyczne Arcta w Warszawie stosowało znak litery A na tle liry (z promieniami rozchodzącymi się na boki) $^{39}$. Leon Idzikowski także umieszczał ten instrument na drukach muzycznych jako znak firmowy ${ }^{40}$, a od około 1911 roku stosował symbol bardziej wysublimowany - lirę (wyposażoną w nazwę firmy) z ramionami otaczającymi kulę ziemską z orbitą, co zapewne dawało wyraz ambicjom wydawcy, który już wtedy wykazywał imponujący zasięg: obok logotypu wydawnictwa były wymienione siedziby w Warszawie i Kijowie, a także liczne miasta carskiej Rosji, w której Idzikowski miał przedstawicieli, jak Wilno, Odessa, Petersburg, Moskwa, Woroneż itp. aż po Władywostok ${ }^{41}$.

Oficyna Gebethner i Wolff (sygnująca się znakiem sowy) publikowała utwory w serii Stowarzyszenia Miłośników Dawnej Muzyki w Warszawie (współzałożonego w 1926 roku przez skrzypka, organizatora życia muzycznego i wydawcę Tadeusza Ochlewskiego), które w swoim znaku graficznym umieściło lirę tworzącą jakby wazon z kwiatami, wyrastającymi z jej trzech strun ${ }^{42}$. Towarzystwo Wydawnicze Muzyki Polskiej (powstałe w 1928 roku także z inicjatywy T. Ochlewskiego $^{43}$ ) sygnowało swoje publikacje bardzo oryginalnie skonstruowanym znakiem, wyraźnie inspirowanym lirą korbową (dawniej zwaną po prostu lirą), mocno związaną z polską oraz słowiańską tradycją muzyczną. Lirę korbową przedstawiono w układzie pionowym, podkreślając symetryczne linie jej konturów i części mechanizmu, co prawdopodobnie miało nawiązywać do symetrii kształtu liry antycznej. Korba w znaku graficznym została pominięta, natomiast w miejscu komory kołkowej instrumentu został wpisany czteroliterowy skrót TWMP. Dwie faliste linie obok prostych (odwzorowujących struny) mogły nawiązywać do drgań strun i ruchu korby. Autorem sygnetu w kształcie liry korbowej był najprawdopodobniej Edward Manteuffel, który odpowiadał za stronę graficzną okładek To-

38 Na przykład G. de Machaut, Oeuvres, Monaco, cop. 1977, https://dlib.rsl.ru/viewer/01004 469757\#?page=2 (dostęp: 25.05.2021).

39 Na przykład J.S. Bach, 15 Inwentions a 2 voix [sic!], revue par A. Różycki, Warszawa [ok. 1945], https://polona.pl/item/15-inwentions-a-2-voix,NzI1MzY1OTY/4/\#info:metadata (dostęp: 28.04.2021).

40 Na przykład E. Ohlsen, Lotosblumen: Walzer, Kieff [non ante 1905], https://polona.pl/item/ lotosblumen-walzer-op-100,MTA1Njk2NzUz/0/\#info:metadata (dostęp: 1.05.2021).

41 Na przykład J.S. Bach, Six sonates pour violon seul, Kieff-Varsovie et al., [po 1911], https:// polona.pl/item/six-sonates-pour-violon-seul,MTI2ODU5MTk/6/\#info:metadata (dostęp: 1.05.2021).

42 Na przykład S.S. Szarzyński, Sonata a due violini e basso... z 1706 r., Warszawa [ok. 1928].

43 M. Sieradz, ,,Kwartalnik Muzyczny” (1928-1950) a poczatki muzykologii polskiej, Warszawa 2015, s. 119-121. 
warzystwa $^{44}$. Na okładkach nut wydawanych przez TWMP, ujednoliconych pod względem graficznym, opisany znak w kształcie liry miał znacznie większe rozmiary niż zwyczajowe sygnety wydawnictw, co sprawiało, że pełnił funkcję nie tylko znaku graficznego wydawnictwa, lecz także ilustracji ${ }^{45}$.

Ten sam znak liry korbowej, lecz ze zmienionym skrótem literowym na PWM, pojawił się w 1945 roku na okładkach Polskiego Wydawnictwa Muzycznego, kontynuatora TWMP. Motyw ludowego instrumentu został zaprojektowany w czasach przedwojennych, więc jego użycie nie wynikało z podkreślania związków $\mathrm{z}$ muzyką tradycyjną $\mathrm{w}$ okresie PRL, choć z powodów propagandowych mogło odpowiadać wizji władzy. Ten oryginalny znak był stosowany przez oba wydawnictwa bez względu na styl czy gatunek utworu muzycznego - spotkamy go na okładce utworu Concertino na skrzypce z fortepianem Grażyny Bacewicz (il. 1), Preludium i fugi Karola Szymanowskiego ${ }^{46}$ oraz przeróżnych programach związanych ze szkolnictwem muzycznym, wydawanych przez PWM.

Ze względu na tragiczną śmierć Manteuffla wprowadzenie zmian w znaku graficznym liry korbowej, czyli włączenie inicjałów założonego w 1945 roku Polskiego Wydawnictwa Muzycznego, musiało przypaść innej osobie. Być może uczynił to Tadeusz Ochlewski, łączący trzy wymienione inicjatywy muzyczne: SMDM, TWMP oraz założone przez siebie PWM, w którym był przez lata dyrektorem. Według słów prof. Mieczysława Tomaszewskiego Ochlewski sam niekiedy wykonywał projekty graficzne w $\mathrm{PWM}^{47}$. Już pierwsza publikacja nutowa tego wydawnictwa, opublikowana w 1945 roku - Romans na skrzypce z fortepianem Aleksandra Zarzyckiego, nosiła na okładce sygnet z lirą korbową ${ }^{48}$. Odmienne w porównaniu do dawnych okładek TWMP były proporcje w rozmieszczeniu elementów okładki oraz wąska bordiura, złożona z wielokrotnie powtórzonych, stylizowanych (i trudnych do odczytania) liter PWM, połączonych znakiem trzystru-

44 Edward Manteuffel (1908-1940) — polski grafik, zajmował się różnymi formami sztuki użytkowej. Był autorem między innymi okładek przedwojennego „Kwartalnika Muzycznego”. W 1937 roku otrzymał złoty medal na Międzynarodowej Wystawie Sztuki i Techniki w Paryżu. Zginął w 1940 roku, zamordowany w Charkowie przez NKWD. M. Sieradz, ,, Kwartalnik Muzyczny”, (1928-1950) a początki muzykologii polskiej, Warszawa 2015, s. 120, 376, 517; Encyklopedia PWN online, https://encyklopedia.pwn.pl/haslo/Manteuffel-Edward;3937360.html (dostęp: 1.08.2021).

45 Na przykład R. Statkowski, Kwartet nr 5, Warszawa 1929, https://imslp.org/wiki/File:Stat_ SQ5_cover.jpg (dostęp: 22.05.2021); J. Maklakiewicz, Pieśń o burmistrzance, sł. J. Kasprowicz, Warszawa 1930, https://bibliotekapiosenki.pl/publikacje/Kasprowicz_Jan_Piesn_o_burmistrzance (dostęp: 22.05.2021).

46 Na przykład K. Szymanowski, Preludium i fuga na fortepian, Kraków 1946, https://polona. $\mathrm{pl} /$ item/preludium-i-fuga-na-fortepian,NzQ5NDA1MDM/0/\#info:metadata (dostęp: 28.04.2021).

47 J. Nowicka, op. cit., s. 8-9.

48 A. Zarzycki, Romans na skrzypce i fortepian, oprac. I. Dubiska, Kraków 1945. J. Nowicka (op. cit., s. 12, ilustracje s. 36, 37) podaje tę publikację jako prawdopodobny katalogowy numer jeden PWM, a projekt tej okładki i podobnych z lat pięćdziesiątych XX wieku jest określony jako projekt redakcji. Nazwisko Edwarda Manteuffla ani sygnet w kształcie liry korbowej nie są wspomniane w monografii J. Nowickiej. 
nowej liry, tym razem antycznej. Nie podano autora projektu okładki - miał to być projekt redakcji. Z czasem zaprzestano używania sygnetu PWM w kształcie liry korbowej, zastępując go projektem prof. Mieczysława Tomaszewskiego, złożonym z samych liter ${ }^{49}$.

W okresie powojennym coraz rzadziej widuje się znak liry antycznej na polskich drukach muzycznych. Miało to związek z wygaszeniem działalności prywatnych oficyn wydawniczych o tradycjach przedwojennych (Arcta czy Idzikowskiego), a PWM nie przyjęło starożytnej liry jako sygnetu. Jako jedna z nielicznych Spółdzielnia Wydawnicza „Czytelnik”, o profilu literacko-humanistycznym, publikująca między innymi nuty umieszczała na nich różne rodzaje bordiur z lirą w miejscu sygnetu wydawnictwa ${ }^{50}$.

\section{Lira w winietach}

Dla okładek i kart tytułowych dziewiętnastowiecznych nut charakterystyczne były winiety - kompozycje graficzne bardzo często zawierające motywy muzyczne w postaci instrumentów, rozmieszczonych samodzielnie lub w rękach muz, niekiedy dekoracyjnie zebranych w grupy na wzór panopliów. Wizerunki instrumentów nie miały na ogół żadnego związku z repertuarem prezentowanym w danej publikacji. W funkcji symbolicznej występuje niezwykle często antyczna lira, jak na przykład w winiecie Gebethnera i Wolffa (podpisanej jako litografia Mękarskiego) - anioł dmie tu w trąbę, stąpając po zwoju nut leżących na kitarze i trzymając wieniec wawrzynu nad medalionem, w którym umieszczono portret Chopina (?) ${ }^{51}$ (il. 3). W wypadku utworów polskiego kompozytora zwraca uwagę nieobecność jakiegokolwiek odniesienia do fortepianu, lecz nie jest to przypadek odosobniony, lecz raczej typowy dla ilustracji nut dziewiętnastowiecznych ${ }^{52}$ lira była wystarczającym symbolem muzyki i najwyższych szczytów artyzmu.

49 J. Nowicka, op. cit., s. 8-9.

50 Na przykład W. Szpilman, Znak pokoju: na głos i fortepian, sł. B. Ostromęcki, Warszawa 1953, http://archiwum.bibliotekapiosenki.pl/Szpilman_Wladyslaw_Al_Legro_Znak_pokoju_na_ glos_i_fortepian (dostęp: 22.05.2021); idem, Nad wiślana wodą: na głos i fortepian, sł. S.R. Dobrowolski, Warszawa, cop. 1952, http://archiwum.bibliotekapiosenki.pl/Szpilman_Wladyslaw_Al_Legro_ Nad_wislana_woda_na_glos_z_fortepianem (dostęp: 22.05.2021). Dziękuję Kamili Staśko-Mazur za wskazanie mi tych okładek. W obu przypadkach portal Cyfrowa Biblioteka Polskiej Piosenki podaje jako projektanta okładki Witolda Rudzińskiego (tożsamego z kompozytorem W. Rudzińskim?).

51 Opis okładki: Utwory Fryd. Chopin'a [sic!] do śpiewu, Warszawa [ok. 1882], wewnątrz opracowanie mazurka F. Chopina op. $24 \mathrm{nr} 1$ pod nazwą To nie on: mazurek, oprac. J. Nowakowski, sł. B. Wisłocki, Warszawa [1882], https://polona.pl/item/to-nie-on-mazurek-op-24-no-1,ODU4NDg2NTc/2/ \#info:metadata (dostęp: 1.05.2021). Choć nie udało się odnaleźć nut innego kompozytora z tą samą winietą, mogła służyć kolejnemu aktualnie prezentowanemu w publikacji muzykowi, niezależnie od instrumentu, na który tworzył.

52 Kolejny przykład to zbiór Fr. Chopin's Pianoforte Werke, rev. Carl Mikuli, Bd. 11. Impromptus, Fr. Kistner, Leipzig [ok. 1900], (zbiory prywatne) — tu centralne miejsce winiety zajmuje 
Warto wspomnieć najbardziej charakterystyczne winiety muzyczne, znane każdemu muzykowi korzystającemu z nut wydawanych przez najważniejsze dziewiętnastowieczne oficyny. Utrzymana w stylu klasycystycznym winieta lipskiego wydawnictwa C.F. Peters (zał. 1800), najczęściej spotykana w nutach z okresu około 1880-1930, ma wkomponowane dwie antyczne liry ${ }^{53}$. Po prawej stronie Erato trzyma kitarę z plektronem, po lewej śpiewająca Kalliope (?) — zwój papieru. Muzy stoją na postumentach wspieranych przez łabędzie (ptaki poświęcone Apollinowi), a ponad nimi, w górnej części winiety dwa putta $\mathrm{z}$ wieńcami laurowymi otaczają piękną siedmiostrunną lirę o ramionach z rogów zwierzęcych, którą wieńczy promieniująca sześcioramienna gwiazda. Kompozycja plastyczna odnosi się zarówno do antyku, jak i Starego Testamentu, i w konsekwencji także chrześcijaństwa - lirę na szczycie winiety można interpretować nie tylko jako symbol sztuki muzycznej, lecz także atrybut samego Boga.

Stosowana w pierwszej połowie XX wieku winieta wiedeńskiej oficyny Universal Edition (zał. 1901) wykazuje wiele zbieżności do wcześniej omówionego Petersa $^{54}$. Jest utrzymana w stylu secesyjnym, a postaci muz, ukazane w postawie siedzącej, nie mają już cech posągów - ich sylwetki i stroje są znacznie swobodniejsze, a twarze i fryzury dziewczęce. Muza po prawej stronie trzyma kitarę, druga po przeciwnej - tamburyn. Winietę wieńczy, wśród drzew i zieleni, fantazyjna kitara o czterech strunach i ramionach z dwóch szyi łabędzich. Elementami łączącymi obie wymienione winiety są parzyste i podobnie rozmieszczone muzy, liry i łabędzie, nie licząc gałązek wawrzynu i dekoracyjnych ornamentów roślinnych.

Bardzo interesujące i oryginalne ilustracje okładek stosowała na przełomie XIX i XX wieku oficyna Cotta'sche Buchhandlung Nachfolger ze Stuttgartu. Przykładowo sonaty klasyków wiedeńskich zostały opatrzone winietą całkowicie inspirowaną starożytnością — architekturą (dwie potężne kolumny w porządku jońskim ujmujące kompozycję po bokach) i sceną mitologiczną (konkursu muzycznego?), umieszczoną ponad lustrem winiety, z aż czterema postaciami lirników oraz trębaczy i perkusistów ${ }^{55}$. Tego rodzaju winieta mogłaby towarzyszyć także wydaniom książek odnoszących się do antyku, kontekst muzyczny jest tu subtelny, wynika z ważnej funkcji muzyki w kulturze starożytnej Grecji. Choć data tego druku została określona na 1928 rok, prawdopodobnie sama winieta

uskrzydlona muza (anioł) z sześcioramienną gwiazdą nad głową i kitarą w dłoniach, otoczona puttami z pochodniami.

53 Na przykład F. Chopin, Chopin-Album: Sammlung der beliebtesten Pianofortewerke, rev. H. Scholtz, Leipzig [ok. 1900], https://polona.pl/item/chopin-album-sammlung-der-beliebtesten-pia nofortewerke,ODM3MzUzNzk/4/\#info:metadata (dostęp: 24.05.2021).

${ }^{54}$ Na przykład F. Chopin, Mazurkas, oprac. R. Pugno, Wien-Leipzig [ok. 1910], ilustrator nieznany, https://polona.pl/item/mazurkas-nach-den-original-uberlieferungen-revidierte-mit-fingersat zen-und,MTE2MzQxMzkz/6/\#info:metadata (dostęp: 28.04.2021).

55 W.A. Mozart, Sonate No. 4 F dur für das Pianoforte. Instruktive Ausgabe, (Edition Cotta No. 373), Stuttgart-Berlin 1928, https://polona.pl/item/sonate-fur-das-pianoforte-kv-547-a-135-no4-f-dur,NzkyMTE0MTk/0/\#info:metadata (dostęp: 24.05.2021). 
powstała wcześniej i była powielana w kolejnych latach. Na rok 1927 jest datowana bliźniacza winieta tego samego wydawcy, utrzymana w podobnym stylu, lecz nakreślona swobodniejszą kreską z delikatnymi ornamentami secesyjnymi, a w miejscach kolumn jońskich umieszczono postaci muzy $\mathrm{z}$ harfą oraz Apolla $\mathrm{z}$ kitarą. Scena mitologiczna na szczycie winiety tym razem zawiera aż pięciu muzyków grających na kitarach, włączając zaś postać Apolla — jest ich sześciu, co jest bodaj rekordem w liczbie lirników antycznych na okładce nut ${ }^{56}$. W kolejnej $\mathrm{z}$ winiet tego wydawnictwa, sygnowanej przez F. Thierscha w 1896 roku, zastosowanej do zbioru nut muzyki fortepianowej na szczycie umieszczono medalion z podobizną kompozytora Carla Marii Webera oraz rysunki fortepianu z grającymi puttami ${ }^{57}$. To jeden z nielicznych przypadków dostosowania treści winiety do repertuaru z epoki późniejszej niż barok. Kompozycja składa się z licznych dziecięcych postaci o skrzydłach anielskich lub motylich, grających na instrumentach charakterystycznych w ikonografii dla okresów nie wcześniejszych niż klasycyzm - fortepianie (o sylwetce właściwej też klawesynowi), wiolonczeli, skrzypcach czy trąbce. Schodząc w dół winiety, widzimy bardziej neutralne pod względem epoki instrumenty czy działania, jak śpiew, harfę, trójkąt, talerze czy kotły, jednak nawet tam znajduje się kontekst antyczny — w dole kompozycji już nie dziecięce aniołki, lecz małe syleny, siedząc w pobliżu kozła, grają na instrumentach dętych - fletni Pana i podwójnym aulosie (?). W kontekście bożka Pana antyczna lira nie byłaby stosowna. W ilustracji widać połączenie realizmu (instrumentarium typowe dla klasycyzmu i późniejszych epok) oraz mitologii, a znajomość przeciwstawności symboli apollińskich i dionizyjskich jest tu odczuwalna (utwór opatrzony tą okładką jest taneczny).

Współcześnie (mniej więcej od drugiej połowy XX wieku) winiety na okładkach lub kartach tytułowych z motywem instrumentów muzycznych są stosowane głównie w seriach nutowych, zawierających tak zwaną muzykę dawną (od średniowiecznej do barokowej) i nierzadko zaczerpnięte z dawnych druków. Zwykle są to dekoracje utworzone z instrumentów charakterystycznych dla renesansu i baroku: lutni, wiol, organów itp. (zdarzają się także antyczne liry), co dość swobodnie odnosi się do repertuaru, zamieszczonego w publikacji ${ }^{58}$. Podobne winiety można spotkać w publikacjach niezawierających nut, ale dotyczących muzyki, na przykład na traktatach muzycznych.

56 W.A. Mozart, Sonate No. 1 C dur für das Pianoforte. Instruktive Ausgabe, (Edition Cotta No. 370), Stuttgart-Berlin 1927, https://polona.pl/item/sonate-fur-das-pianoforte-no-1-c-dur,Nzkz ODIyMTY/0/\#info:metadata (dostęp: 24.05.2021).

57 Na przykład C.M. von Weber, Aufforderung zum Tanz: Rondo brilliant op. 65 Des dur für das Pianoforte, współp. F. Liszt (Edition Cotta nr 448), Stuttgart, cop. 1892, https://polona.pl/item/ aufforderung-zum-tanz-rondo-brillant-op-65-des-dur-fur-das-pianoforte,OTQwMzk2MDU/0/\#info :metadata (dostęp: 24.05.2021).

58 Na przykład czeska seria wydawnictwa Státní hudební vydavatelství pt. „Musica Viva Historica", ozdobiona winietą złożoną z motywów dekoracyjnych z instrumentami takimi jak lutnie, wiole itp. 


\section{Lira jako ozdobnik}

Oprócz wymienionych sposobów włączania liry w ilustracje okładki spotkać ją można także jako ozdobnik, małą formę dekoracyjną. W takiej roli spotkamy ten instrument zarówno w wydawnictwach muzycznych, jak i zawierających, nomen omen, lirykę $e^{59}$. Ozdobnikiem wielu wydawnictw z przełomu XIX i XX wieku jest lira opracowana graficznie w stylu secesyjnym ${ }^{60}$. Instrument ciekawie prezentuje się na okładkach nut z pieśniami wojskowymi (żołnierskimi). Jako symbol pieśni w kontekście wojennym lira bywa łączona nie tylko z wieńcem laurowym, lecz także flagą narodową oraz współczesną bronią. Na okładce nut „Repertuar Wojskowych Zespołów Artystycznych" nr 23, wydanej przez Dom Wojska Polskiego, umieszczono ozdobnik z lirą i typową dla drugiej wojny światowej pepeszą (radzieckim pistoletem maszynowym $)^{61}$ (il. 2). Sporadycznie na okładkach spotkać można nawet dwie liry w różnych funkcjach — w sygnecie wydawnictwa oraz jako ozdobnik, jak w wypadku Pieśni solowych Moniuszki wydanych przez Wydawnictwo Muzyczne Arcta z okładką projektu Marii Szaniawskiej-Bilińskiej62. Na marginesie można wspomnieć, że w XIX wieku bardzo często chóry i przeróżne zespoły wokalne obierały nazwę ,lutnia”, był to także częsty tytuł śpiewników (na przykład Lutnia polska, Lutnia dziecięca), tymczasem okładki publikacji o takim tytule bardzo często ozdabia wizerunek nie lutni, lecz liry ${ }^{63}$. Spotykane są też serie nutowe z lirą w tytule (na przykład „Lira Polska” - seria publikowana przez Gebethnera i Wolffa) pozbawione jakiegokolwiek znaku graficznego z tym instrumentem - tytuł był wystarczająco znaczący.

\section{Lira na ilustracji okładkowej}

Lira w rękach muzykującej postaci na jednostkowej ilustracji okładkowej (nie jako powtarzalna winieta) pojawia się dość rzadko w porównaniu do innych instrumentów, współczesnych ilustratorom, ponieważ zwykle wymaga kontekstu antycznego lub ujęcia metaforycznego. Mimo rodowodu liry jako instrumentu

59 Zob. J. Górski, op. cit., s. 104, przypis B — przykład zastosowania symbolu liry, wytłoczonego na tomiku poezji Leopolda Staffa Wiklina, proj. Maria Dolna.

60 Na przykład F. Liszt, Cantique d'amour: Piano solo, oprac. I. Friedman, Wien 1927, https:// polona.pl/item/cantique-d-amour,NzQ2OTgxNDU/0/\#info:metadata (dostęp: 28.04.2021).

61 „Repertuar Wojskowych Zespołów Artystycznych” nr 23 (zawiera między innymi Pluton przodowników, muz. H. Swolkień, sł. J. Zalewski), Warszawa [ok. 1955], projektant okładki nieznany; w zbiorach prywatnych.

62 S. Moniuszko, Pieśni solowe, według pierwodruków oprac. J. Lefeld, t. 2, z. 1, Warszawa, cop. 1947, proj. okładki M. Szaniawska-Bilińska. Zachowane w zbiorach prywatnych.

63 Zob. liczne przykłady w Polonie, https://polona.pl/search/?query=lutnia\&filters=public:1 (dostęp: 1.05.2021). 
mitycznych mężczyzn - Apolla, Hermesa i Orfeusza, w ikonografii zdecydowanie przeważają postaci kobiet-muz z tym instrumentem. Przykładem może być kolekcja Images Musicales, w której znajdziemy kilkanaście okładek z lirami w dłoniach antycznych muzykantek ${ }^{64}$, natomiast pojedyncze w rękach postaci męskiej ${ }^{65}$. Postaci muz wydają się pretekstem do ukazania urodziwych młodych kobiet, niekiedy półnagich (zgodnie z konwencją Poezja jest przedstawiana z odsłoniętą piersią), przystrojonych $\mathrm{w}$ zwiewne szaty. Występują one na okładkach nut niemal zawsze solo, ewentualnie w parze lub grupie z innymi muzami, rzadko jako inspiracja widocznego na okładce artysty ${ }^{66}$. Niekiedy postać z lirą jest ujęta jakby na pograniczu realizmu i mitologii, ujęcie plastyczne kojarzy się z wizją romantyczną, oniryczną, tak na okładce utworu Leokadii Woyciechowskiej W godzinę zmroku. Pieśń bez stów — w dość swojskim krajobrazie, nad brzegiem jeziora pojawia się kobieta $\mathrm{z}$ lirą w zwiewnej szacie, z odkrytym ramieniem, rozpuszczonymi włosami i o bosych stopach ${ }^{67}$. Ponieważ utwór nie zawiera tekstu, nie narzuca także interpretacji - ilustracja okładki może budzić skojarzenie nie tylko z antyczną muzą, lecz także postacią z ludowej mitologii.

\section{Lira jako symbol ludowych korzeni}

Jako symbol muzyki wokalnej, lira mogła pojawić się w kontekście powrotu do korzeni muzycznych, sprawy tożsamości narodowej lub etnicznej przez odniesienie do pieśni ludowych. Objawia się to w rzadkich ilustracjach, na których starożytna lira (kitara) jest umieszczona w rękach szczególnej muzy — wiejskiej dziewczyny, jak na okładce pierwszych dwóch numerów czasopisma poświęconego muzyce polskiej na Śląsku „Nuta Polska” wydanego w 1925 roku w Katowicach, w okresie trudnym odnośnie do utrzymania tożsamości i określenia przynależności państwowej Śląska ${ }^{68}$ (il. 4). Dziewczyna w stroju ludowym jest przedstawiona na tle krajobrazu, jak gdyby była częścią natury - czerwone kwiaty z jej spódnicy jakby wysypują się na łąkę, są tej samej barwy co korale i część

64 Niektóre ilustracje umieszczone w tej grupie to zresztą nie liry, lecz harfy lub lutnie. Strona Images Musicales z grupą lir: https://www.imagesmusicales.be/search/topic/Lyres/659/ShowData/8/Submit/page-1/ (dostęp: 1.05.2021).

65 Na przykład Album der Jongeren. Vlaamsche Muziek nr. 12, Antwerpen, s.a. [ok. 1900?], https://www.imagesmusicales.be/browse/item/7186/8/ (dostęp: 24.05.2021).

66 Zob. https://www.imagesmusicales.be/search/topic/Muses/1409/ShowData/8/Submit/page-1/ (dostęp: 1.05.2021).

67 L. Woyciechowska, $W$ godzinę zmroku. Pieśń bez słów, Leon Idzikowski, Warszawa-Kijów, cop. 1924 (seria: „Lira Polska”), cyt. za: A. Banach, op. cit., s. 9; zob. Mazowiecka Biblioteka Cyfrowa, http://mbc.cyfrowemazowsze.pl/dlibra/doccontent?id=44645 (dostęp: 1.05.2021).

68 „Nuta Polska. Miesięcznik poświęcony literaturze, muzyce, sztuce i pieśni polskiej” 1, 1925, nr 1 i 2 (litografia i druk Leopold Nowak), https://www.sbc.org.pl/dlibra/publication/103521/edi tion/97432? (dostęp: 1.05.2021). 
instrumentu, liście drzewa kolorystycznie zlewają się z barwą włosów i kitary, sama zaś kitara jest naturalnym atrybutem muzy, jednak nasuwa na myśl realny instrument ludowy, zwłaszcza lirę korbową (w komentarzach wewnątrz czasopisma nazwano postać z okładki lirniczką). Na okładce numeru 3-4 (prawdopodobnie ostatniego wydanego „Nuty Polskiej”) ilustrację z ludową muzą zastąpiono okolicznościowym zdjęciem, jednak znakiem graficznym czasopisma, umieszczonym przy tytule, pozostała ozdobna kitara. Podobny wizerunek ludowej muzy znajdziemy na okładce Lutni Polskiej. Zbioru pieśni narodowych Polskich i Ukrainskich zebranych przez Adama Wrońskiego - dziewczyna w stroju ludowym gra na antycznej lirze, a pod nią, aby podkreślić międzynarodowy charakter pieśni, umieszczono znaki trzech krajów i narodów: Archanioła Michała, Orła Białego i Pogoń ${ }^{69}$. Mały Krakowiaczek, ,podtrzymujący” kartę z tytułem, dopełnia obraz polskości i odniesień regionalnych. Gdyby postaci wiejskich muzykantek potraktować bardziej realnie, decyzja o wyborze instrumentu muzycznego byłaby problematyczna, ponieważ w polskiej praktyce ludowej na instrumentach muzycznych grali mężczyźni, a kobietom przypadał śpiew — co podkreśla symboliczny charakter postaci kobiecych na omawianych okładkach.

\section{Metafora}

Wracając do poszukiwania różnic między ilustracjami zawierającymi instrumenty muzyczne na okładkach nut i książek, można wskazać na metaforę. Tematyka ilustracji okładek nut $\mathrm{z}$ reguły $\mathrm{w}$ dość bezpośredni sposób łączy się z treścią utworów muzycznych, zwłaszcza przez słowa piosenek czy pieśni, ale także przez kompozytora, repertuar czy instrument, na który skomponowano czy zaaranżowano utwór. W repertuarze miłosnym spotkamy zwykle ilustracje z parą kochanków, niekiedy z gitarą, lutnią lub przy fortepianie, a w repertuarze tanecznym całe orkiestry, od saksofonu po perkusję. Poza opisanymi wcześniej znaczeniami, jakie niesie starożytna lira, ilustracje z użyciem metafory na okładkach nut są rzadko spotykane. Funkcja ta może wystąpić $\mathrm{z}$ większą siłą w ilustracji książkowej, jeśli wypływa z głębszej literackiej treści. Przykładem jest ilustracja na okładce utworów scenicznych Sławomira Mrożka wykonana przez Andrzeja Darowskiego (zaprezentowana w zbiorze Tysiac polskich okładek ${ }^{70}$ ). Widnieje na niej tuba, której przewód (rura) przekształca się płynnie w ludzkie, połączone z sobą, wnętrzności

69 Lutnia Polska. Część druga. Zbiór pieśni narodowych Polskich i Ukraińskich, ułożył na fortepian A. Wroński, Kraków [1898-1903] (ilustrator nieznany), https://polona.pl/item/lutnia-polska-czesc-druga-zbior-piesni-narodowych-polskich-i-ukrainskich-op-157,MzQwNTc4ODg/0/\#info:m etadata (dostęp: 1.05.2021).

70 Tysiąc polskich okładek, s. 660; S. Mrożek, Utwory sceniczne nowe, Kraków 1975, zob. https://lubimyczytac.pl/ksiazka/107482/utwory-sceniczne-nowe (dostęp: 24.05.2021). 
— serce, płuca, jelita czy nerki. Niektóre z cielesnych przewodów są przecięte. Instrument muzyczny z okładki staje się ciałem, jego działanie - metaforą cielesnego życia. Instrument dęty brzmi tylko wtedy, gdy wprowadzi się do niego powietrze, podobnie jak oddychanie jest warunkiem życia każdej żywej istoty. Na okładce Darowskiego wnętrzności wyrastające z instrumentu muzycznego zapewne odnoszą się do utworu Rzeźnia, którego bohaterem jest muzyk, a sednem refleksja nad sensem sztuki w odniesieniu do przemocy fizycznej i jej popularności.

\section{Detale}

Rzadko bohaterem okładek i kart tytułowych jest samodzielny instrument, zajmujący całą ich powierzchnię, lub ilustracje skupione na detalach instrumentu muzycznego. W tej roli także wykorzystany bywa wizerunek liry, jak w serii „Sounds from Fairy Land” nowojorskiej oficyny American Music Publishing, w której ogromny instrument jest owinięty szarfą z wypisanymi tytułami utworów muzycznych w niej publikowanych. Podstawę liry wykorzystano jako miejsce na nazwę wydawcy ${ }^{71}$. Jednym z najciekawszych przykładów na detale instrumentu muzycznego w ilustracji okładkowej (tym razem książki) jest wydana przez PWM biografia Niccolò Paganiniego pióra Józefa Powroźniaka ${ }^{72}$. Autor ilustracji Daniel Mróz zestawił dwie główki skrzypiec $\mathrm{z}$ wieńczącymi je ślimakami, otaczając je dynamicznymi, „rytmicznymi” wzorami graficznymi. Okładka, utrzymana w tonacji czarno-białej, jest artystycznie bardzo udana. Umiejętnie wskazuje na tematykę książki — główną rolę skrzypiec w biografii muzyka, równocześnie wykorzystuje potencjał części instrumentu — intrygujących, spiralnych linii ślimaków, omijając ryzykowny banał „cielesnego” kształtu korpusu.

\section{Zakończenie}

Lira to prawdopodobnie jedyny instrument muzyczny o tak dużej mocy w sferze symbolicznej - w kulturze europejskiej, nawiązującej do antyku, niezwykle długo funkcjonująca jako symbol, choć w praktyce muzycznej zamilkła kilkanaście wieków temu. Mimo że od XIX wieku najważniejszym instrumentem był fortepian, którego interesujący kontur predysponował go do bycia nośnym symbolem graficznym, nie dostąpił on tego rodzaju uwznioślenia i zuniwersali-

71 Faust's Wildfang galop (seria „Sounds from Fairy Land”), New York [ok. 1890], https:// repository.duke.edu/dc/hasm/a3030 (dostęp: 24.05.2021).

72 Tysiąc polskich okładek, s. 256: J. Powroźniak, Paganini, Kraków 1958, zob. https:// pl.pinterest.com/pin/415527503093276931/ (dostęp: 24.04.2021). Jest to bodaj najlepsza okładka muzyczna w zbiorze Tysiąc polskich okładek opracowanym przez Mizielińskich. 
zowania. Lira stała się symbolem uniwersalnym, łączyła muzykę instrumentalną i wokalną, wszelkie rodzaje i gatunki sztuki muzycznej, a nawet - jak wykazały przykłady - mogła patronować twórczości ludowej. Uniwersalne znaczenie liry w sferze symbolicznej XIX wieku łatwiej uchwycić, obserwując warstwę ilustracyjną nut, książek, przedmiotów związanych z muzyką, niż obserwując dzieła $\mathrm{z}$ gatunku malarstwa czy rzeźby.

Na przełomie XIX i XX wieku, gdy znaczenie mediów muzycznych wzrosło, a popularność zdobyły nowe gatunki muzyki rozrywkowej, na ilustrowanych okładkach nut zaczęły się pojawiać dawniej niespotykane w tym kontekście instrumenty, jak saksofon, kontrabas, całe orkiestry przygrywające do tańca czy zespoły jazzowe. Znaczenie antycznej liry wydaje się z czasem maleć w tym medium. Jednak nie zanika, lecz pojawia się w nowym otoczeniu — staje się częstym elementem znaków firmowych wytwórni płyt lub ich etykiet — przykładem jest znak graficzny polskiej firmy Syrena Record, w którym lira umieszczona jest na gramofonie, skrzyżowana $\mathrm{z}$ jego dwiema tubami ${ }^{73}$.

Współcześnie, często mylona z harfą, lira coraz rzadziej funkcjonuje jako powszechnie rozpoznawalny symbol muzyczny, choć w sferze sygnetów wydawnictw muzycznych nadal utrzymuje mocną pozycję, wynikającą z tradycji. Jej znaczenie ogólnomuzyczne będzie zapewne trwało tak długo, jak długo żywa pozostanie symbolika antycznych muz i ich atrybutów.

\section{The lyre on sheet music covers}

\section{Abstract}

This paper examines sheet music cover art featuring musical instruments in the nineteenth and the first half of the twentieth century. The ancient lyre, the preeminent instrument of ancient Greece, is one of the most frequently depicted instruments on sheet music covers. Although it has been absent from Western practice for hundreds of years, its significance as a symbol of music, particularly vocal-instrumental, persists. Lyres appear on sheet music covers in a variety of roles, from (often inconspicuous) publishers' logos to small decorative additions to main cover images. Conventionally, the lyre is depicted by itself or in the hands of the Muses, who are sometimes visually modernized or stylized to reference folk art. Although in the nineteenth and twentieth centuries it was the piano that was the most popular instrument, often featured in sheet music illustrations, it failed to achieve the same prominence in the visual field as the lyre. The ancient lyre remains a universal symbol of music. It seems, however, that the recognition of the instrument and its symbolic meaning, as well as its mythological and religious references, is declining.

Keywords: Musical instruments, sheet music, sheet music covers, cover illustrations, lyre, ancient lyre, classical lyre, lyre symbolism, Apollo, the Muses, piano, publisher's logo, musical iconography

73 Zob. etykiety Syrena Record, a także innych wydawców płyt: https://staremelodie.pl/etykie ty/all (dostęp: 1.06.2021). 


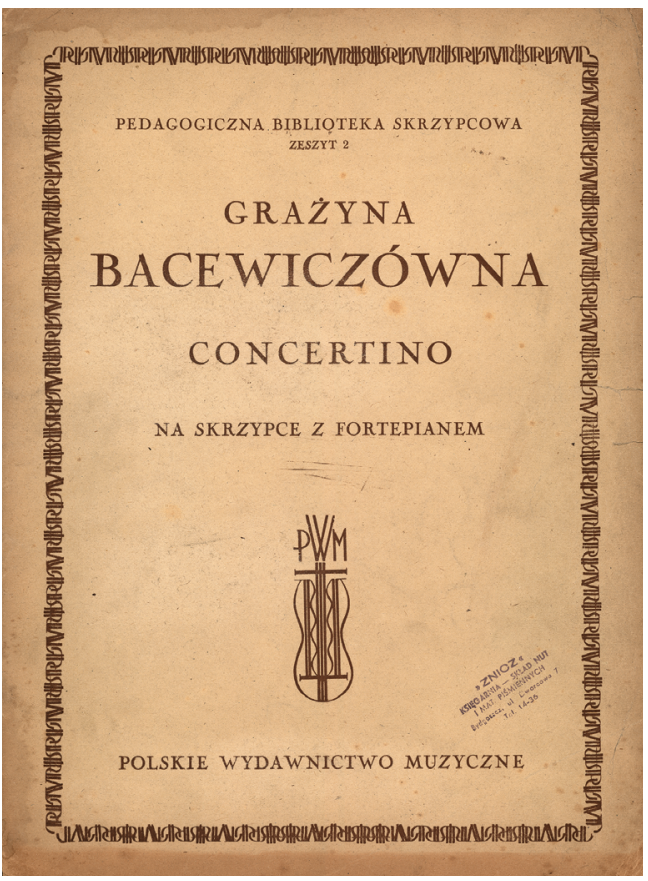

Ilustracja 1. Grażyna Bacewiczówna, Concertino na skrzypce z fortepianem, PWM, Kraków 1950, okładka: projekt redakcji

Źródło: prywatne zbiory autorki.

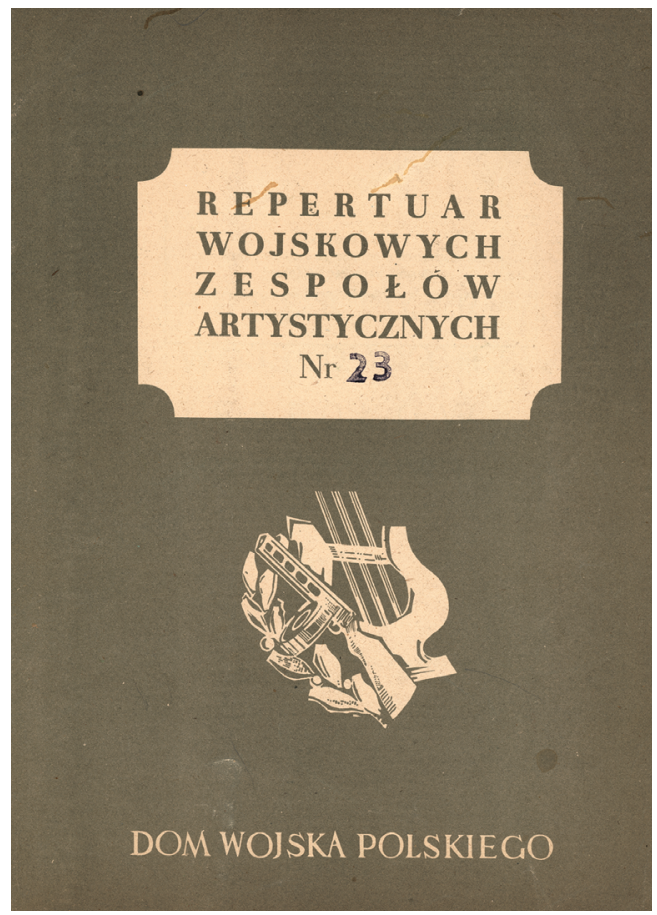

Ilustracja 2. Repertuar wojskowych zespołów artystycznych, nr 23, Dom Wojska Polskiego, Warszawa 1955, okładka: projektant nieznany Źródło: prywatne zbiory autorki. 


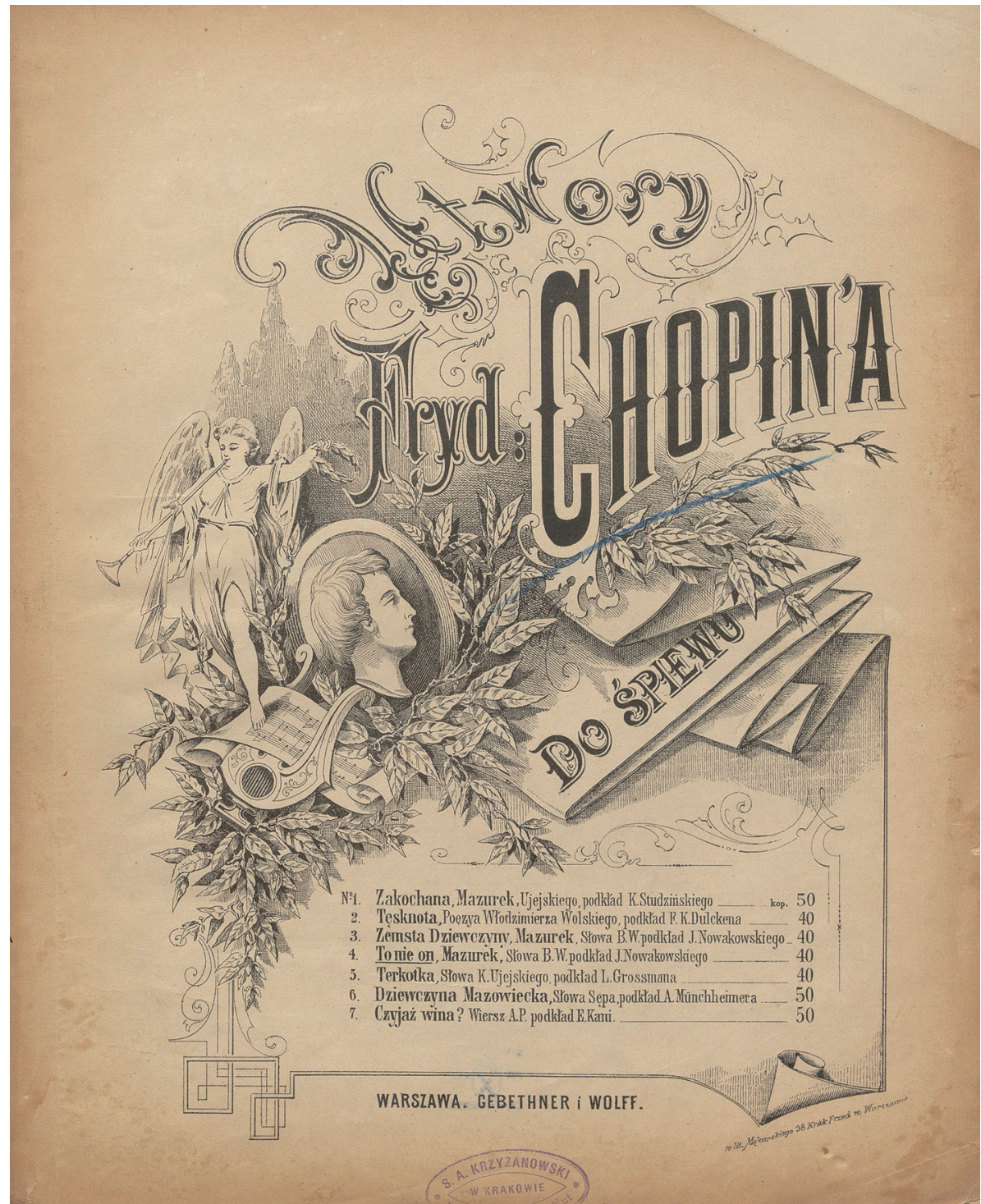

Ilustracja 3. Utwory Fryd. Chopin'a [sic!] do śpiewu, Gebethner i Wolff, Warszawa [ca 1882], okładka: litografia [J.] Mękarskiego

Źródło: Polona.pl, https://polona.pl/item/to-nie-on-mazurek-op-24-no-1,ODU4NDg2NTc/2/\#info:metadata. Miejsce przechowywania: Biblioteka Jagiellońska, sygn. BJ Muz. 10268 III 4. 


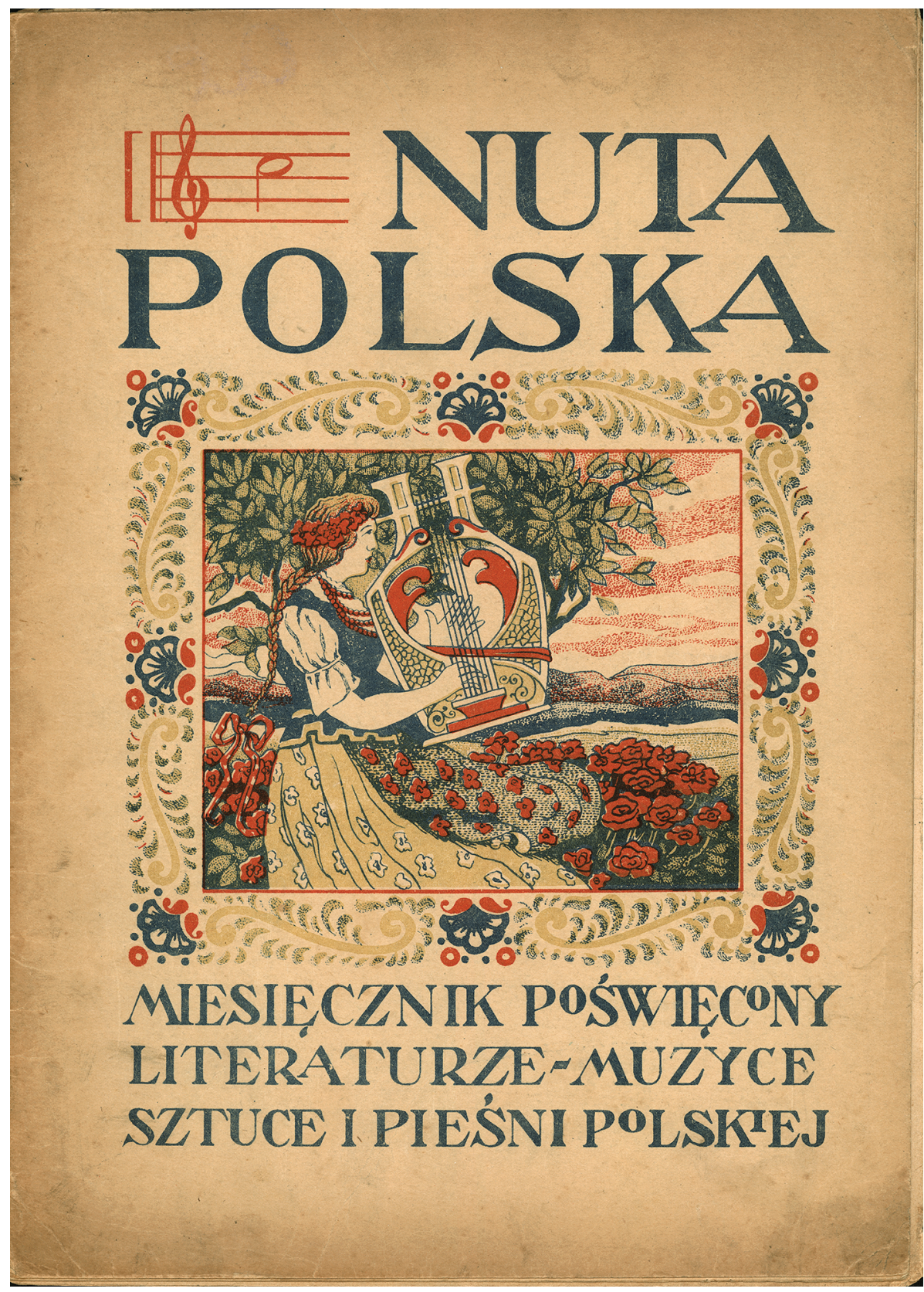

Ilustracja 4. „Nuta polska. Miesięcznik poświęcony literaturze, muzyce, sztuce i pieśni polskiej” 1, 1925, nr 1, okładka: litografia Leopold Nowak

Źródło: prywatne zbiory autorki. 


\section{Bibliografia}

Banach A., Lekcja z nut, Kraków 1971.

Cirlot J.E., Stownik symboli, przeł. I. Kania, Kraków 2000.

Cohen E.S., Kruschwitz A.L., Old age in America represented in nineteenth and twentieth century popular sheet music, „The Gerontologist” 30, 1990, nr 3, s. 345-354

Encyklopedia muzyki, red. A. Chodkowski, Warszawa 2001.

Feuillet M., Leksykon symboli chrześcijańskich, przeł. M. Paleń, Poznań 2006.

Górski J., Dosłownie. Liternicze i typograficzne okładki polskich książek 1944-2019, Kraków 2019.

Kennedy Ch.A., "Becky from Babylon" and Other Oriental Beauties: Images of Middle Eastern Women in Twentieth-Century Sheet Music, „Music in Art” 42, 2017, nr 1-2, s. 353-365.

Kwintus Horacjusz Flakkus (Horacy), Dzieła wszystkie, t. 1, oprac. O. Jurewicz, przeł. J. Sękowski, Wrocław 1986.

Łubocki J.M., Okładki druków muzycznych jako ważne zagadnienie badawcze: na marginesie wystawy Obrazki z nut (Wroctaw, 19 stycznia-28 lutego 2018), „Studia o Książce i Informacji” 37, 2018.

Mała encyklopedia kultury antycznej, red. Z. Piszczek, Warszawa 1983.

Melbechowska-Luty A., Chopin w malarstwie polskim od romantyzmu do modernizmu, [w:] Chopin w kulturze polskiej, red. M. Gołąb, Wrocław 2009.

Montagu J., Instrumenty muzyczne Biblii, przeł. G. Kubies, Kraków 2006.

Muzyka w sztukach wizualnych XIX-XXI wieku, red. J. Guzy-Pasiak, Warszawa 2013 (Ikonografia muzyczna. Studia i materiaty, t. 2).

Nowicka J., 70 na 70. Projektowanie graficzne w PWM w latach 1945-2015, red. M. Bielatowicz, Kraków 2015.

Obrazki z nut. Druki muzyczne od końca XIX do połowy XX wieku z kolekcji Pawła Banasia. Wystawa w Dolnoślaskiej Bibliotece Publicznej im. Tadeusza Mikulskiego we Wrocławiu. Styczeń/luty 2018, red. J. Czarnik, A. Ćwik, Wrocław 2018.

Sachs C., Historia instrumentów muzycznych, przeł. S. Olędzki, Warszawa 2005.

Sieradz M., ,, Kwartalnik Muzyczny” (1928-1950) a początki muzykologii polskiej, Warszawa 2015.

Towarek P., Chrześcijańska symbolika instrumentów muzycznych, „Studia Elbląskie” 15, 2014, s. $221-232$.

Tysiac polskich okładek, wyb. A. i D. Mizielińscy, Warszawa 2010.

Wachsmann K., Lawergren B., Weisser S., Wegner U., Lyre, [w:] The Grove Dictionary of Musical Instruments, red. L. Libin, t. 3, New York 2014, s. 344-347.

Zgliński M., Cover design in editions of Polish propaganda songs, 1945-1955, [w:] Music, Politics and Ideology in the Visual Arts, red. P. Gancarczyk, D. Grabiec, Warszawa 2015 (Ikonografia muzyczna. Studia i materiaty, t. 3), s. 139-151.

\section{Źródła internetowe}

Artaria, https://www.artaria.com.

Attenborough: the amazing Lyre Bird sings like a chainsaw! Now in high quality (film w serii „BBC

Earth"), https://www.youtube.com/watch? $=$ mSB71jNq-yQ.

Batuty w zbiorach polskich, www.batuty.instrumenty.edu.pl.

Encyklopedia PWN online, https://encyklopedia.pwn.pl/haslo/Manteuffel-Edward;3937360.html.

Historic American Sheet Music, https://repository.duke.edu/dc/hasm.

Images Musicales, https://imagesmusicales.be/about/8/.

Der letzte Operettenkönig, https://www.musikundbuehne.de/specials/franz-lehar.html. 
Library of Congress, Music for the Nation: American Sheet Music, ca. 1870 to 1885, https://www. loc.gov/collections/american-sheet-music-1870-to-1885/.

Schott, https://de.schott-music.com/eulenburg/ueber-eulenburg.

Stare Melodie, https://staremelodie.pl.

Wystawa okładek nut w Ostromecku, http://konferencjainstrumentologiczna.pl/1320.

\section{Cytowane ilustracje z okładek nut, czasopism i książek}

Album der Jongeren. Vlaamsche Muziek $n r .12$, Antwerpen, s.a. [ok. 1900?], https://www.images musicales.be/browse/item/7186/8/.

Bacewiczówna G., Concertino na skrzypce z fortepianem, PWM, Kraków 1950, projekt redakcji. Bach J.S., 15 Inwentions a 2 voix [sic!], revue par A. Różycki, Warszawa [ok. 1945], https://polona. $\mathrm{pl} /$ item/15-inwentions-a-2-voix,NzI1MzY1OTY/4/\#info:metadata.

Bach J.S., Inwencje dwugłosowe na fortepian, Kraków 2020, https://pwm.com.pl/pl/sklep/publika cja/inwencje-dwuglosowe,johann-sebastian-bach,536,ksiegarnia.htm.

Bach J.S., Six sonates pour violon seul, Kieff, Varsovie et al., [po 1911], https://polona.pl/item/sixsonates-pour-violon-seul,MTI2ODU5MTk/6/\#info:metadata.

The Beauties of Psalmody: A collection of sacred music..., arr. D. Robertson, Edinburgh [ok. 1800], https://polona.pl/item/the-beauties-of-psalmody-a-collection-of-sacred-music-suitable-to-pub lic-or-private,MTAxMDA3MzQ1/4/\#info:metadata.

Beethoven L. van, Symphonie V C-moll, Wien [1923], https://polona.pl/item/symphonie-v-c-moll-cminor-do-mineur-op-67,ODY3NTMwOTY/0/\#info:metadata.

Chopin F., Chopin-Album: Sammlung der beliebtesten Pianofortewerke, rev. H. Scholtz, Leipzig [ok. 1900], https://polona.pl/item/chopin-album-sammlung-der-beliebtesten-pianofortewerke,O DM3MzUzNzk/4/\#info:metadata.

Chopin F., Mazurkas, oprac. R. Pugno, Wien, Leipzig [ok. 1910], ilustrator nieznany, https://polona. $\mathrm{pl} /$ item/mazurkas-nach-den-original-uberlieferungen-revidierte-mit-fingersatzen-und,MTE2Mz QxMzkz/6/\#info:metadata.

Faust's Wildfang galop (seria „Sounds from Fairy Land”), New York [ok. 1890], https://repository. duke.edu/dc/hasm/a3030.

Fr. Chopin's Pianoforte Werke, rev. Carl Mikuli, Bd. 11. Impromptus, Leipzig [ok. 1900].

Grieg E., Walc op. 12, Poznań 1950, https://polona.pl/item/walc-op-12-na-fortepian,Njg5MDc0NT M/0/\#info:metadata.

Liszt F., Cantique d'amour: Piano solo, oprac. I. Friedman, Wien 1927, https://polona.pl/item/can tique-d-amour,NzQ2OTgxNDU/0/\#info:metadata.

Lutnia Polska. Część druga. Zbiór pieśni narodowych Polskich i Ukraińskich, ułożył na fortepian A. Wroński, Kraków [1898-1903], https://polona.pl/item/lutnia-polska-czesc-druga-zbior-pies ni-narodowych-polskich-i-ukrainskich-op-157,MzQwNTc4ODg/0/\#info:metadata.

Machaut G. de, Oeuvres, Paris [ok. 1980?], https://www.europeana.eu/en/item/9200474/Bibliograp hicResource_3000149430842.

Maklakiewicz J., Pieśń o burmistrzance, sł. J. Kasprowicz, Warszawa 1930, https://bibliotekapio senki.pl/publikacje/Kasprowicz_Jan_Piesn_o_burmistrzance.

Moniuszko S., Pieśni solowe, według pierwodruków oprac. J. Lefeld, t. 2, z. 1, Warszawa, cop. 1947, proj. okładki M. Szaniawska-Bilińska.

Mozart W.A., Sonate No. 1 C dur für das Pianoforte. Instruktive Ausgabe, Stuttgart-Berlin 1927 (Edition Cotta No. 370), https://polona.pl/item/sonate-fur-das-pianoforte-no-1-c-dur,NzkzOD 5IyMTY/0/\#info:metadata. 
Mozart W.A., Sonate No. 4 F dur für das Pianoforte. Instruktive Ausgabe, Stuttgart-Berlin 1928 (Edition Cotta No. 373), https://polona.pl/item/sonate-fur-das-pianoforte-kv-547-a-135-no-4-fdur,NzkyMTE0MTk/0/\#info:metadata.

Mrożek S., Utwory sceniczne nowe, Kraków 1975, https://lubimyczytac.pl/ksiazka/107482/utwory -sceniczne-nowe.

„Nuta Polska. Miesięcznik poświęcony literaturze, muzyce, sztuce i pieśni polskiej” 1, 1925, nr 1 i 2, litografia i druk Leopold Nowak, https://www.sbc.org.pl/dlibra/publication/103521/edition/97432/content.

Ohlsen E., Lotosblumen: Walzer, Kieff [nie przed 1905], https://polona.pl/item/lotosblumen-walzerop-100,MTA1Njk2NzUz/0/\#info:metadata.

Panofka H., The Art of singing: Twenty-four vocalizes for Alto, New York [ok. 1930], https://polona. $\mathrm{pl} /$ item/the-art-of-singing-twenty-four-vocalises-for-alto-baritone-or-bass-op-81, OTQzMTc1O DA/4/\#info:metadata.

Powroźniak J., Paganini, Kraków 1958, https://pl.pinterest.com/pin/415527503093276931/.

„Repertuar Wojskowych Zespołów Artystycznych” nr 23, Warszawa [ok. 1955].

Stare Melodie, etykiety płyt Syrena Record i in., https://staremelodie.pl/etykiety/all.

Statkowski R., Kwartet $n r$ 5, Warszawa 1929, https://imslp.org/wiki/File:Stat_SQ5_cover.jpg.

Szarzyński S.S., Sonata a due violini e basso... z 1706 r., Warszawa [ok. 1928].

Szpilman W., Nad wiślana woda: na głos i fortepian, sł. S.R. Dobrowolski, Warszawa, cop. 1952, proj. okładki Witold Rudziński, http://archiwum.bibliotekapiosenki.pl/Szpilman_Wladyslaw_ Al_Legro_Nad_wislana_woda_na_glos_z_fortepianem.

Szpilman W., Znak pokoju: ña głos i fortepian, sł. B. Ostromęcki, Warszawa 1953, proj. okładki Witold Rudziński, http://archiwum.bibliotekapiosenki.pl/Szpilman_Wladyslaw_Al_Legro_Znak_ pokoju_na_glos_i_fortepian.

Szymanowski K., Preludium i fuga na fortepian, Kraków 1946, https://polona.pl/item/preludium-i -fuga-na-fortepian,NzQ5NDA1MDM/0/\#info:metadata.

Utwory Fryd. Chopin'a [sic!] do śpiewu, Warszawa [ok. 1882], wewnątrz: To nie on: mazurek, oprac. J. Nowakowski, sł. B. Wisłocki, Warszawa [1882], https://polona.pl/item/to-nie-on-ma zurek-op-24-no-1,ODU4NDg2NTc/2/\#info:metadata.

Wagner R., Tristan und Isolde: Vorspiel und Isoldes Liebestod, Leipzig [ok. 1920], https://polona.pl/ item/vorspiel-und-isoldens-liebestod-aus-tristan-und-isolde,MTExMjIyMjc0/0/\#info:metadata.

Weber C.M. von, Aufforderung zum Tanz: Rondo brilliant op. 65 Des dur für das Pianoforte, bearb. F. Liszt, Stuttgart, cop. 1892 (Edition Cotta nr 448), https://polona.pl/item/aufforderung-zumtanz-rondo-brillant-op-65-des-dur-fur-das-pianoforte,OTQwMzk2MDU/0/\#info:metadata.

Wieniawski H., Kujawiak, Riga [ok. 1930], https://polona.pl/item/kujawiak-piano,NzE3MTYxNz $\mathrm{Y} / 0 /$ \#info:metadata.

Woyciechowska L., W godzinę zmroku. Pieśń bez słów, Warszawa-Kijów, cop. 1924 (Lira polska), http://mbc.cyfrowemazowsze.pl/dlibra/doccontent?id=44645.

Wydanie Narodowe Dzieł Fryderyka Chopina, https://www.chopin-nationaledition.com/sklep/ ?lang=pl.

Zarzycki A., Romans na skrzypce i fortepian, oprac. I. Dubiska, Kraków 1945.

$$
* * *
$$

Joanna Gul — teoretyk muzyki, instrumentolog, współpracuje z Instytutem Muzykologii Uniwersytetu Wrocławskiego oraz Pracownią Badań Pejzażu Dźwiękowego UWr. Zainteresowania skupia na instrumentach muzycznych, ich historii i dokumentacji, muzycznych aspektach wystaw rzemieślniczo-przemysłowych oraz zagadnieniach audiosfery. Od 2014 roku współpracuje przy dokumentacji instrumentów muzycznych w polskich muzeach dla portalu Instrumenty.edu.pl prowadzonego przez 
Instytut Muzyki i Tańca. Publikowała między innymi w czasopismach „Muzyka”, „Ruch Muzyczny”, „Prace Kulturoznawcze”, „Audiosfera: Koncepcje — Badania — Praktyki”. Współorganizuje cykliczne ogólnopolskie konferencje instrumentologiczne z ramienia Instytutu Muzykologii UWr. Prowadzi zajęcia dydaktyczne dla studentów muzykologii Uniwersytetu Wrocławskiego oraz podyplomowych studiów „Dźwięk i Audiosfera”.

joanna.gul@uwr.edu.pl 